Шило Ж. С. [1; ORCID ID: 0000-0002-2669-6734], к.е.н., доцент,

Гапонюк Л. О. [1; ORCID ID: 0000-0001-9046-4578], здобувачка вищої освіти другого (магістерського) рівня

${ }^{1}$ Національний університет водного господарства та природокористування, м. Рівне

\title{
МЕТОДИ ОЦІНКИ САНАЦІЙНОЇ СПРОМОЖНОСТІ ТА БАНКРУТСТВА ПІДПРИЕМСТВ ХАРЧОВОЇ ПРОМИСЛОВОСТІ
}

В статті наведено основні підходи до визначення поняття «санаційної спроможності» підприємства. Детально охарактеризовані особливості методики оцінки санаційної спроможності та створення дієвих механізмів управління підприємствами харчової промисловості. На основі проведеного аналізу запропоновано систему показників для визначення доцільності проведення санаційних заходів та встановлення процедури банкрутства.

Ключові слова: санація; санаційна спроможність; банкрутство; механізм оцінки санаційних заходів; підприємства харчової промисловості.

Постановка проблеми. В умовах фінансової та політичної нестабільності діяльність підприємств супроводжується кризовими ситуаціями, результатом яких може стати неплатоспроможність або банкрутство. Сприятливим підґрунтям для виникнення такої ситуації найчастіше стають прорахунки в стратегічних планах і в наборі тактичних заходів, які не повною мірою дозволяють підприємству знайти успішний вихід з кризової ситуації.

На практиці використовується недостатньо як загальних теоретико-методичних розробок з питань управління санацією, так i спеціальних, призначених для підприємств окремих галузей, що зі свого боку не дозволяє ефективно організувати роботу підприємств в кризових умовах. Це обумовлює необхідність в розробці теоретикометодичного забезпечення процесів управління санацією підприємств, формування їі організаційно-економічного механізму, як важливого інструменту оздоровлення, відновлення ефективної системи управління і конкурентоспроможності підприємств в сучасних умовах господарювання.

Аналіз публікацій. Проблеми розробки інструментарію оцінки санаційної спроможності та створення дієвих механізмів управління підприємством в умовах економічних трансформацій досліджували такі вітчизняні та зарубіжні вчені, як І.Ансофф, Т.Білоконь, 


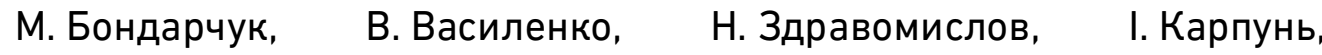
А. Кондрашихін,
К. Ларіонова,
Л. Лігоненко,
О. Мозенков,

В. Москаленко, , Б. Поляков, О. Раєвнєва, О. Терещенко, О. Тридід.

Незважаючи на велику кількість розроблених методичних підходів, сьогодні не існує чітко окресленого інструментарію оцінки санаційної спроможності та банкрутства підприємств харчової промисловості.

Метою статті є визначення економічної сутності поняття «санаційна спроможність» підприємства та аналіз основних підходів до їі оцінки. А також обґрунтування теоретико-методичних засад і практичних рекомендацій щодо формування та застосування механізму банкрутства на підприємствах харчової промисловості.

Для досягнення поставленої мети нами окреслено такі завдання: систематизувати теоретичні підходи щодо сутності та групування основних видів санації; удосконалити науковометодичний інструментарій для оцінки й аналізу санаційного потенціалу підприємств; дослідити дію механізму банкрутства підприємств харчової промисловості.

Основний розділ. В умовах економічної кризи та невизначеності вітчизняних підприємств їх діяльність виявилася не стійкою до дії негативних факторів зовнішнього середовища. В такій ситуації виникає необхідність визначення ступеня стійкості підприємства в несприятливих, загрозливих умовах функціонування. Одним із засобів подолання загальної економічної кризи та запобігання банкрутству підприємства $€$ проведення фінансової санації.

Термін «санація» походить від латинського «sanare» i перекладається як оздоровлення або видужання. Економічний словник трактує це поняття як систему заходів, що здійснюються для запобігання банкрутством промислових, торгових, банківських монополій. Санація може відбуватися способом об'єднання підприємства, яке перебуває на межі банкрутства, з потужнішою компанією; за допомогою випуску нових акцій або облігацій для мобілізації грошового капіталу; збільшення банківських кредитів і надання урядових субсидій; перетворення короткострокової заборгованості в довгострокову; повної або часткової купівлі державою акцій підприємства, що перебуває на межі банкрутства.

Проте, на нашу думку, таке трактування цілей санації, механізму іï проведення та переліку санаційних заходів $\epsilon$ недостатньо чітко окресленим, оскільки запобігання банкрутству ще не означає оздоровлення та повний вихід підприємства з фінансової 
кризи, а названі заходи, по-перше, не є вичерпними i, по-друге, не розкривають принципових методологічних підходів до вибору тих чи інших форм проведення санації.

Основоположним та найбільш раціональним трактуванням санації в теорії та на практиці вважається визначення, запропоноване відомими зарубіжними економістами Н. Здравомисловим, М.Гелінгом, Б.Бекенферде, які вважають санацію системою фінансово-економічних, виробничо-технічних, організаційно-правових та соціальних заходів, спрямованих на досягнення чи відновлення платоспроможності, ліквідності, прибутковості і конкурентоспроможності підприємства-боржника в довгостроковому періоді [12]. Таке визначення було використано сучасними вченими-економістами, такими як Подєрьогін А. М., Терещенко О. О., Карпунь І. Н., Білоконь Т. М., Мартиненко В. П., Багацька К. В. та іншими, проте поряд зі спільною думкою зазначених авторів існують також інші трактування санації.

Дослідивши наукові праці, присвячені питанню санаційної спроможності, нами наведено порівняльну характеристику основних методичних підходів до їі оцінки (таблиця).

Таблиця

Порівняльна характеристика методичних підходів до оцінки санаційної спроможності підприємства

\begin{tabular}{|c|c|c|}
\hline Автор & $\begin{array}{c}\text { Характерні особливості } \\
\text { запропонованої методики }\end{array}$ & $\begin{array}{c}\text { Основні недоліки } \\
\text { запропонованої методики }\end{array}$ \\
\hline 1 & 2 & 3 \\
\hline О.О. Терещенко & $\begin{array}{l}\text { Значна увага приділяється } \\
\text { наступним аспектам: аналізу } \\
\text { виробничої } \\
\text { підприємства, оцінюктури } \\
\text { рівня існуючої технології } \\
\text { виробництва, аналізу витрат } \\
\text { на виробництво, аналізу } \\
\text { основних засобів та } \\
\text { амортизаційних відрахувань, } \\
\text { аналізу показників праці }\end{array}$ & 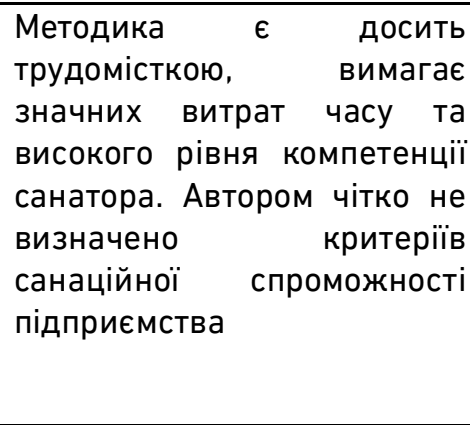 \\
\hline К.В. Багацька & 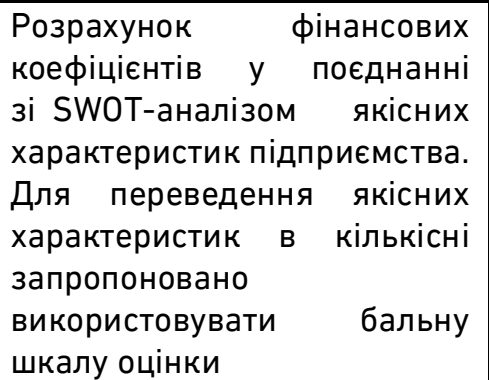 & 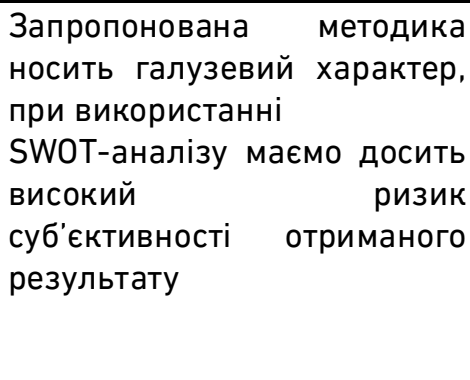 \\
\hline
\end{tabular}


продовження таблиці

\begin{tabular}{|c|c|c|}
\hline Ю.М. Бурлака & $\begin{array}{l}\text { Алгоритм оцінки санаційної } \\
\text { спроможності передбачає } \\
\text { здійснення 7-9 етапів, які } \\
\text { містять спеціальні типи } \\
\text { оцінок і спрямовані на } \\
\text { визначення можливостей } \\
\text { підприємства відновити } \\
\text { фінансовийстан }\end{array}$ & $\begin{array}{lc}\text { Методика } & \text { द } \\
\text { громіздкою, усунення даного } \\
\text { недоліку } \\
\text { рахунок можливе } \\
\text { запропонованого алгоритму }\end{array}$ \\
\hline P.І. Грешко & 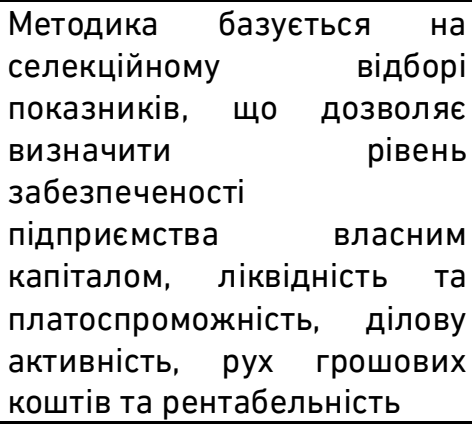 & $\begin{array}{l}\text { Запропонована система } \\
\text { показників характеризує } \\
\text { лише фінансовий стан } \\
\text { суб'єкта господарювання }\end{array}$ \\
\hline Л.І. Лачкова & 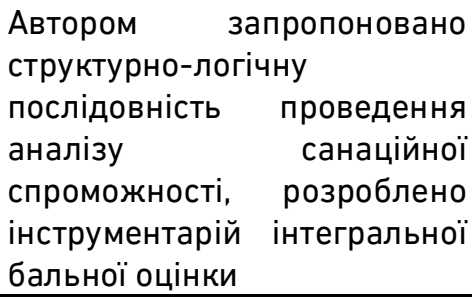 & $\begin{array}{l}\text { Галузева спрямованість } \\
\text { обраних } \quad \text { індикаторів. } \\
\text { Відсутність показників, що } \\
\text { характеризують виробничу } \\
\text { та організаційну структуру } \\
\text { підприємства }\end{array}$ \\
\hline $\begin{array}{l}\text { Н.Здравомислов, } \\
\text { М. Гелінг }\end{array}$ & $\begin{array}{l}\text { Це система фінансово- } \\
\text { економічних, виробничо- } \\
\text { технічних, організаційно- } \\
\text { правових і соціальних } \\
\text { заходів, які направлені на } \\
\text { досягнення або відновлення } \\
\text { платоспроможності, } \\
\text { ліквідності } \\
\text { конкурентоспроможності } \\
\text { підприємства-боржника } \\
\text { довгостроковому періоді }\end{array}$ & $\begin{array}{l}\text { У визначенні } \\
\text { необхідно санації } \\
\text { основними виділити } \\
\text { правові відносини, оскільки } \\
\text { вони є основоположними } \\
\text { протягом усього процесу } \\
\text { санації і визначають мету ії } \\
\text { проведення }\end{array}$ \\
\hline
\end{tabular}

Джерело: складено авторами на основі джерел [7; 12]

Аналізуючи дослідження різних авторів, ми вважаємо, що санація - це економіко-правові відносини між суб'єктами, які викають під час впровадження системи заходів з метою задоволення в повному обсязі або частково вимог кредиторів та оздоровлення фінансово-господарського стану боржника у довготривалій перспективі на основі розвитку та реалізації санаційного потенціалу. 
Виходячи з вищевикладеного, можна зробити висновок, що всі запропоновані методики мають ряд істотних недоліків, що знижує точність оцінки санаційної спроможності при їх застосуванні.

Для визначення санаційної спроможності підприємств харчової промисловості необхідною стає побудова системи показників, які б дозволили адекватно оцінити економічну ситуацію, що склалася на підприємстві. Узагальнення теоретичних підходів та опрацювання даних експертного опитування фахівців у сфері банкрутства вказує на доцільність оцінювання санаційної спроможності підприємств харчової промисловості у розрізі його фінансового, виробничого та організаційного потенціалу [1].

Ми запропонували використовувати певну модель станційної спроможності підприємств харчової промисловості (рис. 1).

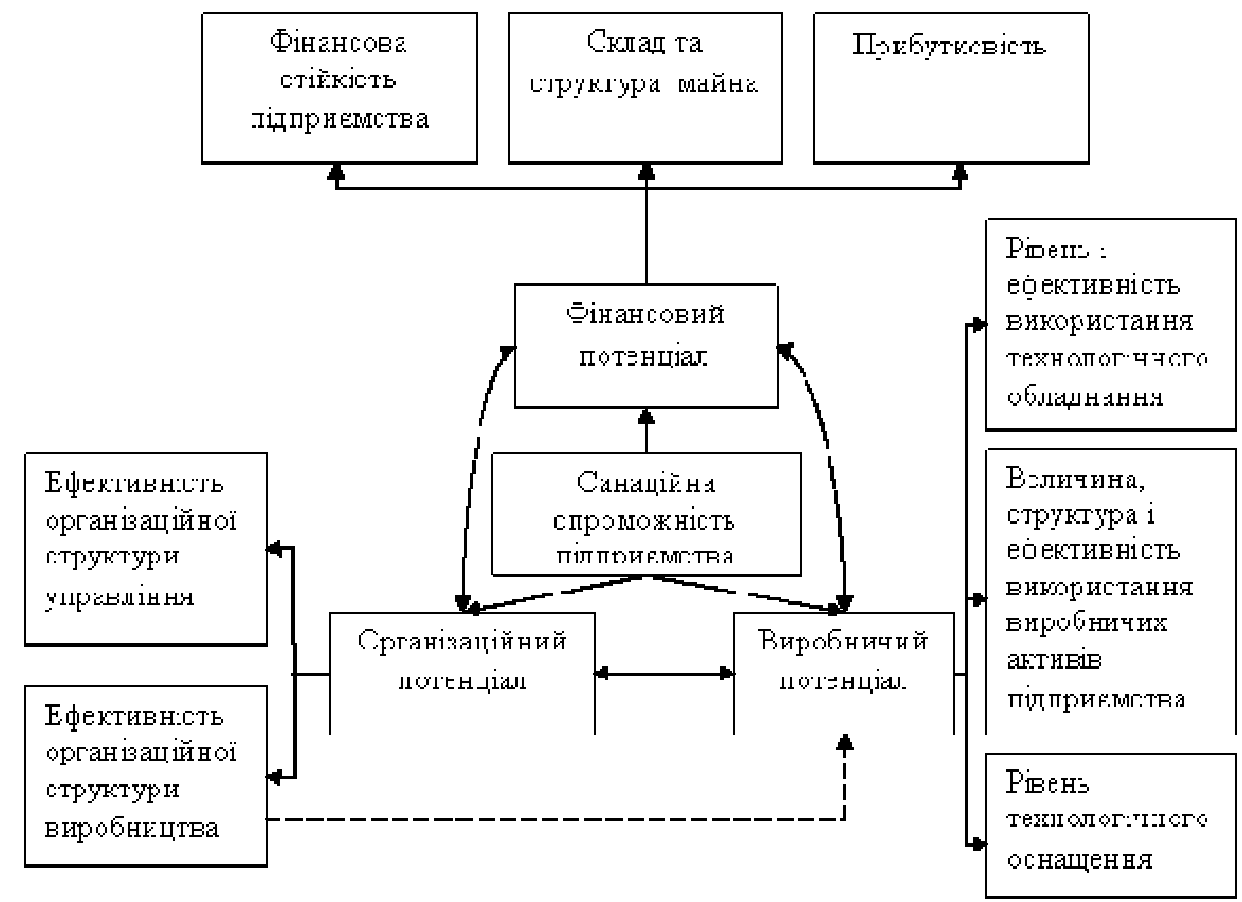

Рис. 1. Система санаційної спроможності підприємств харчової промисловості

Джерело: складено авторами

Обґрунтування доцільності управління санаційними заходами підприємства відбувається на основі інформації про рівень санаційної спроможності суб'єкта господарювання. При цьому особливу увагу слід звернути на показники, які формують базу для оцінювання санаційної спроможності. 
Враховуючи особливості господарської діяльності підприємств харчової промисловості, нами було сформовано систему показників, які характеризують фінансовий, виробничий та організаційний потенціал господарюючого суб'єкта (рис. 2).

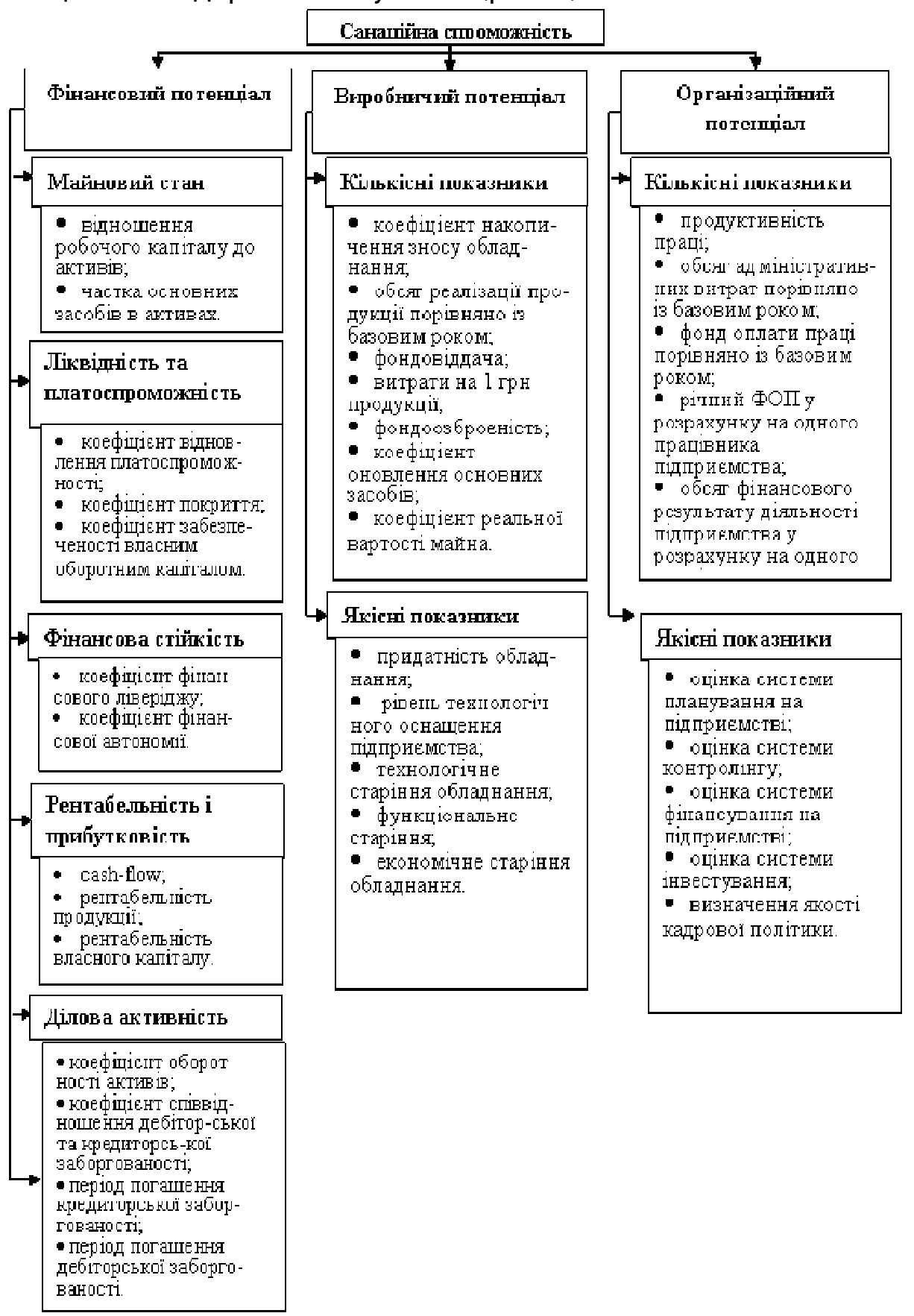

Рис. 2. Сукупність показників для визначення санаційної спроможності підприємств харчової промисловості

Джерело: складено авторами 
Запропонована методика дозволяє не тільки здійснювати оцінку санаційної спроможності підприємства, але й створює передумови до виявлення слабких сторін, які стримують його економічний розвиток в умовах трансформації економічних процесів.

Досліджуючи проблему банкрутства, західні фахівці розробили теорію кризового управління, суть якого полягає в діагностиці стану фірми і розробці заходів щодо виходу з кризи або вибору способу припинення ії діяльності, коли вона стає банкрутом. Кризове управління має на меті збереження підприємства як економічної одиниці, одним із таких напрямків $€$ консолідація [5].

Консолідація передбачає проведення заходів спрямованих на виявлення та подолання причин негативних явищ при одночасному збереженні організаційної структури та продовження виробничої діяльності підприємства. Консолідаційні програми охоплюють організацію праці управління та контроль, а також заходи щодо зниження виробничих витрат.

Консолідаційні програми включають наступне:

- аналіз фінансових показників, дослідження їх динаміки і виявлення найбільш впливових факторів, що погіршують фінансовий стан;

- визначення природи небажаних явищ;

- розробку комплексних і конструктивних заходів;

- реалізацію програми санації, яку доручають кризовим менеджерам, а не працівникам підприємства.

Перевагою консолідації є збереження організаційної цілісності підприємства, його виробничої діяльності та конфіденційного заходу, а загалом, утримання його ринкових позицій [9].

За недостатністю консолідації або санації застосовується так звані трансформаційні методи, які передбачають зміну організаційної структури та юридичного статусу підприємства. При цьому ліквідації підприємства не відбувається, оскільки банківський рахунок і торгівельна марка переходять далі. Вказані варіанти не вичерпують можливостей і способів виживання підприємства, наприклад практикується передача юридичним або фізичним особам на конкурсних засадах функцій управління підприємствомборжником.

Проблема в Україні ускладнюється недосконалістю системи нормативно-правового забезпечення, недопрацюваннями в системі бухгалтерського обліку фінансово-економічної діяльності, що часто унеможливлює діагностику підприємства, а також дефіцитом фахівців з питань кризового управління. 
Висновки. Підводячи підсумки дослідження методів оцінки фінансової санації та банкрутства підприємств харчової промисловості, необхідно відмітити наступне:

1) при розробці методів оцінки санаційної спроможності та банкрутства слід враховувати особливості даної галузі;

2) оцінку банкрутства підприємств харчової промисловості доцільно проводити у розрізі їх фінансового, виробничого та організаційного потенціалу;

3) запровадити для оцінки санаційної спроможності підприємств необхідність проведення санаційного аудиту у межах порушення справи про банкрутство;

4) 3 метою спрощення процедури оцінки санаційної спроможності доцільним $\epsilon$ розробка інтегрального показника визначення необхідності проведення санаційних заходів.

Отже, санаційна спроможність підприємства - це складна економічна категорія, а розробка методів іiї оцінки потребує подальшого дослідження та вдосконалення, що дозволяє перейти до формування принципово нової методики на перспективу.

1. Білоконь Т.М. Санація підприємств: організаційно-економічний механізм : монографія. Вінниця : ВНТУ, 2010. 152 с. 2. Благодєтєлєва-Вовк С. Л. Управління фінансовою санацією підприємств : навч. посіб. К. : Ніка-Центр, 2006. 248 с. 3. Боронос В. Г. Управління фінансовою санацією підприємств : навч. посіб. Суми : Вид-во СумДУ, 2010.437 с. 4. Булович Т. В. Порівняльна характеристика методичних підходів до оцінки санаційної спроможності підприємства. Вісник Хмельницького національного університету. 2009. № 6. С. 11-15. 5. Зінченко О. А. Теоретико-методологічні підходи до удосконалення механізму управління фінансовою санацією підприємства. Вісник Криворізького національного університету. 2013. №34. С. 305-309. 6. Карпунь І.Н.Антикризові заходи на підприємстві: управління, стратегія, цілі та завдання : монографія. Львів : Магнолія, 2008. 440 с. 7. Кондрашихін А. Б. Фінансова санація і банкрутство підприємств : навч. посіб. К. : Центр учбової літератури, 2007. 208 с. 8. Копилюк О. І. Фінансова санація та банкрутство підприємств : навч. посіб. Київ : Центр навчальної літератури, 2009. 168 с. 9. Ларіонова К. Л. Формування складових елементів організаційно-економічного механізму управління санацією підприємства. Вісник Хмельницького національного університету. Економічні науки. 2012. № 6. Т. 2. С. 8794. 10. Манойленко О.В. Підходи до оцінки санаційного потенціалу тимчасово неплатоспроможних суб'єктів господарювання. Економіка і держава. 2010. № 1. С. 60-63. 11. Мостова М. А. Санаційна спроможність підприємств харчової промисловості в сучасних умовах. URL: http://www.nbuv.gov.ua/portal/Soc_Gum/Vcndtu/2011_48/28.htm (дата звернення: 16.09.2020). 12. Терещенко 0.0. Антикризове фінансове управління на підприємстві : монографія. К. : КНЕУ, 2006. 268 с. 


\section{REFERENCES:}

1. Bilokon T. M. Sanatsiia pidpryiemstv: orhanizatsiino-ekonomichnyi mekhanizm : monohrafiia. Vinnytsia : VNTU, 2010. 152 s. 2. Blahodietielieva-Vovk S. L. Upravlinnia finansovoiu sanatsiieiu pidpryiemstv : navch. posib. K. : Nika-Tsentr, 2006. 248 s. 3. Boronos V. H. Upravlinnia finansovoiu sanatsiieiu pidpryiemstv : navch. posib. Sumy : Vyd-vo SumDU, 2010. 437 s. 4. Bulovych T. V. Porivnialna kharakterystyka metodychnykh pidkhodiv do otsinky sanatsiinoi spromozhnosti pidpryiemstva. Visnyk Khmelnytskoho natsionalnoho universytetu. 2009. № 6. S. 11-15. 5. Zinchenko 0. A. Teoretyko-metodolohichni pidkhody do udoskonalennia mekhanizmu upravlinnia finansovoiu sanatsiieiu pidpryiemstva. Visnyk Kryvorizkoho natsionalnoho universytetu. 2013. № 34. S. 305-309. 6. Karpun I. N. Antykryzovi zakhody na pidpryiemstvi: upravlinnia, stratehiia, tsili ta zavdannia : monohrafiia. Lviv: Mahnoliia, 2008. $440 \mathrm{~s}$. 7. Kondrashykhin A. B. Finansova sanatsiia i bankrutstvo pidpryiemstv : navch. posib. K. : Tsentr uchbovoi literatury, 2007. 208 s. 8. Kopyliuk O. I. Finansova sanatsiia ta bankrutstvo pidpryiemstv : navch. posib. Kyiv : Tsentr navchalnoi literatury, 2009. 168 s. 9. Larionova K. L. Formuvannia skladovykh elementiv orhanizatsiinoekonomichnoho mekhanizmu upravlinnia sanatsiieiu pidpryiemstva. Visnyk Khmelnytskoho natsionalnoho universytetu. Ekonomichni nauky. 2012. № 6. T. 2. S. 8794. 10. Manoilenko 0. V. Pidkhody do otsinky sanatsiinoho potentsialu tymchasovo neplatospromozhnykh subiektiv hospodariuvannia. Ekonomika i derzhava. 2010. № 1. S. 60-63. 11. Mostova M. A. Sanatsiina spromozhnist pidpryiemstv kharchovoi promyslovosti $\quad \mathrm{v}$ suchasnykh umovakh. URL: http://www.nbuv.gov.ua/portal/Soc_Gum/Vcndtu/2011_48/28.htm (data zvernennia: 16.09.2020). 12. Tereshchenko 0 . 0 . Antykryzove finansove upravlinnia na pidpryiemstvi : monohrafiia. K. : KNEU, 2006. 268 s.

Shylo Z. S. [1; ORCID ID: 0000-0002-2669-6734], Candidate of Economics (Ph.D.). Associate Professor Haponiuk L. O. [1; ORCID ID: 0000-0001-9046-4578], Master

${ }^{1}$ National University of Water and Environmental Engineering, Rivne

\section{METHODS OF ASSESSMENT OF REHABILITATION AND BANKRUPTCY OF FOOD INDUSTRY ENTERPRISES}

In conditions of financial and political instability, the activities of enterprises are accompanied by crisis situations, which can result in insolvency or bankruptcy. Despite the large number of developed methodological approaches, there are currently no clearly defined tools for assessing the rehabilitation capacity and bankruptcy of the food industry.

The purpose of the article is to determine the economic essence of the concept of "rehabilitation capacity" of the enterprise and analysis of the main approaches to its evaluation. As well as substantiation of theoretical 
and methodological principles and practical recommendations for the formation and application of the bankruptcy mechanism in the food industry.

The term "sanitation" comes from the Latin "sanare" and translates as recovery or recovery. The Economic Dictionary interprets this concept as a system of measures taken to prevent the bankruptcy of industrial, commercial, banking monopolies. Rehabilitation can take place by merging an enterprise that is on the verge of bankruptcy with a more powerful company; by issuing new shares or bonds to mobilize money capital; increase in bank loans and government subsidies; conversion of short-term debt into long-term; full or partial purchase by the state of shares of an enterprise on the verge of bankruptcy.

Analyzing the research of various authors, we believe that the reorganization - is the economic and legal relations between the subjects, which during the implementation of the system of measures to fully or partially meet the requirements of creditors and improve the financial and economic condition of the debtor in the long run development and implementation of remediation potential.

We proposed to use a certain model of station capacity of the food industry. Taking into account the peculiarities of economic activity of food industry enterprises, we have formed a system of indicators, which characterize the financial, production and organizational potential of the business entity.

Summing up the results of the study of methods for assessing the financial rehabilitation and bankruptcy of the food industry, it should be noted the following: when developing methods for assessing the resolution and bankruptcy, it is necessary to take into account the specifics of this industry; it is expedient to assess the bankruptcy of food industry enterprises in terms of their financial, production and organizational potential.

Thus, the rehabilitation capacity of the enterprise is a complex economic category, and the development of methods for its assessment requires further research and improvement, which allows to move to the formation of a fundamentally new methodology for the future.

Keywords: reorganization; reorganization capacity; bankruptcy; mechanism of evaluation of reorganization measures; food industry enterprises. 
Шило Ж. C. [1; ORCID ID: 0000-0002-2669-6734], к.э.Н., доцент,

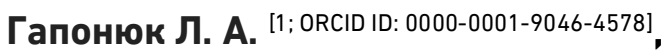
соискательница высшего образования второго (магистерского) уровня

${ }^{1}$ Национальный университет водного хозяйства и природопользования, г. Ровно

\section{МЕТОДЫ ОЦЕНКИ САНАЦИОННОЙ СПОСОБНОСТИ И БАНКРОТСТВА ПРЕДПРИЯТИЙ ПИЩЕВОЙ ПРОМЫШЛЕННОСТИ}

В статье приведены основные подходы к определению понятия «санационной способности» предприятия. Подробно охарактеризованы особенности методики оценки санационной способности и создания действенных механизмов управления предприятиями пищевой промышленности. На основе проведенного анализа предложена система показателей для определения целесообразности проведения санационных мероприятий и установления процедуры банкротства.

Ключевые слова: санация; санационная способность; банкротство; механизм оценки санационных мероприятий; предприятия пищевой промышленности. 